\title{
Examining the Impact of Welfare Facilities on Building Construction Employee's Performance in the Eastern Region of Ghana
}

\author{
Timothy Adu Gyamfi ${ }^{1}$ (), King Solomon Akorli¹, Samuel Osae ${ }^{1}$, Edward Nana Addy $^{2}$ \\ ${ }^{1}$ Faculty of Built and Natural Environment, Koforidua Technical University, Koforidua, Ghana \\ ${ }^{2}$ Faculty of Built Environment \& Applied Science, Sunyani Technical University, Sunyani, Ghana \\ Email: agttimo78@gmail.com, soking1975@yahoo.com, Osaekwaku@yahoo.com,renaddy@yahoo.com
}

How to cite this paper: Gyamfi, T.A., Akorli, K.S., Osae, S. and Addy, E.N. (2021) Examining the Impact of Welfare Facilities on Building Construction Employee's Performance in the Eastern Region of Ghana. Journal of Building Construction and Planning Research, 9, 40-55.

https://doi.org/10.4236/jbcpr.2021.91004

Received: December 10, 2020

Accepted: March 23, 2021

Published: March 26, 2021

Copyright $\odot 2021$ by author(s) and Scientific Research Publishing Inc. This work is licensed under the Creative Commons Attribution International License (CC BY 4.0).

http://creativecommons.org/licenses/by/4.0/

(c) (i) Open Access

\begin{abstract}
Building Construction employees essentially required sufficient welfare facilities such as a place for washing, shower, change over, eat and drink, a place to store and hang clothing. Yet, these fundamental necessities are regularly disregarded. Decent welfare facilities can absolutely promote health and well-being and can aid to avert contracting diseases at building construction site. The aim of this study is to examine the impact of welfare facilities on building construction workers performance in the Eastern Region Ghana. The objectives were to identify welfare facilities provided by building construction firms, evaluate the satisfaction level of building construction firms' employees with welfare facilities in Eastern Region, and determine the relationship between provision of welfare facilities and employee's performance. The study employed convenient sample to investigate 80 building construction employees through questionnaires administration. Data generated from the survey was further analyzed using SPSS, weighted mean formula was used to determine the mean ranking, and descriptive and inferential statistics such as mean score, percentages, frequencies and chi square were used. The study reveals that the extent of welfare facilities at various construction sites was almost unavailability of sanitary and toilet facilities, unavailability of washing facilities, and unavailability of changing room, whiles drinking water and locker facilities were available but not sufficient. The study further finds that construction employees are dissatisfied with the condition of welfare facilities provided at their various work places. The study finally concludes that if workers are provided with decent welfare facilities at various building construction sites, it will motivate them to improve performance. The study recommends that metropolitan, municipal and district authority (MMDAs) should set a task force to check the implementation of welfare facilities at
\end{abstract}


construction site as the results are pointing woeful insufficiency of welfare facilities at Eastern Region construction firms in Ghana.

\section{Keywords}

Welfare Facilities, Construction Site, Eastern Region, Construction Workers, Workers Performance

\section{Introduction}

The complexity of human life is increasingly evolving at this current dispensation as well as the needs and prerequisites. However, individuals become dejected if their needs are not met [1]. Similarly, this can be compared to construction workers; they need some basic welfare facilities at their work place as motivation to their well-being and functioning. According to [2], providing welfare facilities at construction sites is so essential to employee's well-being and health. The Construction Design and Management Regulations [3], and Ghana Labour Act, 2003 [4] postulated the fundamental legal requirement of welfare facilities. Construction Design and Management Regulations [5] make it clear that construction site needs a minimum provision of welfare facilities which must include appropriate toilet and washing facilities, potable drinking water, facilities for storage and rest and a clean place to eat and drink during breaks. HSE [6] and Workplace Health Safety and Welfare (WHSW) Regulation [7], included the provision of first aid on construction site. Hiba [8] posited that in every day's work, employees are required to take water, eat food and snacks, wash and clean their hands, visit wash room and relax to recover from tiredness. Hiba [8] believed that if these welfare facilities are not available for use by worker on site, it will affect their output. However, it is obligatory for contractors to provide suitable welfare facilities at construction site [9], yet the fundamental necessities for welfare facilities are often insufficient and sometimes deserted by some contractors [2]. Welfare facilities can be well-thought-out as a technique of enhancing retention and profit in the organisation. According to [10], employees dissatisfying with insufficient welfare facilities on construction site result in low output as well as loss of profit. The significance of welfare facilities is appreciated by few companies who understand the vital role welfare facilities offer to organisational performance [11]. The worker welfare facility of an organisation has an influence on worker behaviour and the output of the firm. Study conducted by [12] assesses the adequacy of welfare facilities on Construction Sites in Ghana, while [11] researches into Worker Satisfaction with Construction Site Welfare Provisions. However, little research has been done in Ghana to determine the relations between welfare facilities and performance. This research aims at examining how welfare provision affects building construction workers site performance. The study intends to identify welfare facilities provided by building con- 
struction firms in Eastern Region, to evaluate the satisfaction level of employees with welfare facilities in Eastern Region, and to determine the relationship between provision of welfare facilities and employee's performance. Base on provision of welfare facilities and how it is related to performance had led to the orisation of hypothesis for the current study:

$\mathrm{H}_{1}$ : there is significant association between welfare facilities and workers performance.

$\mathrm{H}_{0}$ : there is no significant association between welfare facilities and workers performance.

\section{Human Resource in Construction Site}

According to [13], human resource management (HRM) is the application of human resources efficiently and effectively to accomplish goals of an establishment as cited in [10]. As posited by [10] HRM is basically hinge on hiring and keeping best people to any establishment. Currently, human resource management is a very important functional area of organisational management. Human resources management in an establishment is extremely significant towards realising organisational goals and purposes [13] as cited [10]. The essential resource of every organisation is its worker. Grounded on their essential characters, they can be characterised as the life-blood of an establishment [14]. Accomplishment of the organisational goals and objectives are entirely dependent on its human resource within an organisation, since construction workers form complete body of the establishment which governs and directs the other resources towards the accomplishment of the organisational goals. The acquisition of knowledge, skills and know-how are based on human resource development that adds economic value to firms or organisations. All over the world a study conducted with small, medium, and large companies reveals that workers benefit and reimbursement packages can play a major role in worker retention, improving organisational performance and profitability [15] [16] as cited in [17].

\section{Welfare Facilities Plan for Construction Site}

Provision of health and safety plan for every construction project aids in its successful management such that unanticipated costs and setbacks are reduced to barest minimum [18]. The construction of any facility should give more attention to the planning phase, in other to capture all the necessary welfare provisions. When planning the provision of welfare facilities for construction sites, it is imperative to pay attention to issues such as; the nature of the work to be done, the health risk factors related to work activities, the closeness of welfare facilities to employees; the allocated of the project; the number of workers required for the project; the cleaning and maintenance of the welfare facilities [3] [10]. According to HSE [19], where laws and legislation are applicable, it is significant to addresses provision of welfare facilities in health and safety plan. Ridley et al., [20] said it should be a practice by the contractors to provide adequate 
welfare facilities to its workforce before commencement of every construction activities.

\section{Forms of Welfare Facilities at Construction Site}

Welfare facilities can be categories into two forms namely; intra-mural and extra-mural facilities. Intramural activities involve provision of facilities inside the organisations or construction sites and this includes sick bay, supply of water, washing and bathing facilities, changing rooms, canteens, provision of safety measures, tasks which help in enhancing the conditions of work, and the likes [21]. Whereas, [22] identifies labour welfare as statutory and un-statutory welfare measures. Statutory welfare is obligatory to be provided in establishment, and the existence of every organisation also depends on statutory welfare provision. Their provision must not depend on size of organisation and same should apply to construction industry. These welfares facilities comprise drinking water, facilities for sitting, first Aid, lavatory basins, urinals, restroom, canteen Facilities, lighting, washing places, changing rooms, and rest room [3]. Welfare facilities required for construction sites have been broken down into five main parts namely: sanitary conveniences, washing facilities, drinking water, changing rooms and lockers, and finally facilities for rest [5] [23].

\subsection{Living Accommodations at the Construction Site}

According to Construction Safety Partnership Advisory Committee (CSPAC) [24] contractor is expected to provide the following facilities at or close proximity to the site: sufficient and appropriate accommodation for shelter when encounter bad weather or for keeping clothing after changing for the day, provision of adequate and suitable means for five or more people or five or less people to warm themselves and for drying wet clothing at construction site; provision of adequate and suitable accommodation for keeping used and unused protective clothing, with appropriate measures for drying cloth should they become wet; provision of sufficient and appropriate accommodation with adequate tables with impervious surfaces and seats with backs, for eating meals in acceptable surroundings; provision of facilities for boiling water and for heating food where applicable, availability of facilities for preparing meals inacceptable conditions is necessary. Nevertheless, provision of sufficient supply of potable water and, where applicable, additional appropriate non-alcoholic beverage is delivered at a suitable location; in all these the accommodation provided shall be appropriately ventilated, adequately light, properly clean, hygienic and well arrange condition and not used for disposing of materials and storage of plant.

\subsection{Sanitary and Toilet Facilities at the Construction Site}

According to HSE [2] the sanitary and toilet facilities comprise water closets (WC), portable chemical toilets and urinals. Toilet facilities required consist of flushing toilets with running water which is supply from water mains and WC 
connected to drainage system if possible. Another avenue is to offer facilities with a built-in water supply and drainage container. The British Standard (BS) 6465 code of practice for the design of sanitary facilities and scales of provision of sanitary and related appliances advocates that, there should be sufficient number of toilet provisions on site for the employees. The BS6465 code [25] advocates a ratio of 1:7 for toilet facilities, thus one toilet for seven workers and portable toilet $s$ drained once every week. Whiles, WHSW [7] opines, provision of one toilet, one wash basin, and one urinal is sufficient for every 25 workers. Moreover, where toilet facilities are provided under lockable room it is probable for men and women to use the same facilities. Else separate toilets should be provided. In the view of CSPAC [24] a minimum of one appropriate sanitary convenience should be provided, thus one WC and one urinal is appropriate for every 20 employees at work site; but where 100 employees' or more are found at site, it shall be adequate if there is one such convenience for every 25 persons up to the first 100 and for every 35 persons thereafter; where possible every sanitary convenience should be connected to main sewer, the sanitary convenience premises is made clean, tidy and well ventilated and does not communicate with any workroom except through the open air or through an intervening ventilated space; every sanitary convenience shall be under locked and separated to protected privacy. Similarly, every sanitary convenience should be accessible to peoples at work any times while possible, it should be conveniently located to the washing facilities; and another provision should be made for separate use of sanitary convenience for men and women [7].

\subsection{Washing Facilities at the Construction Site}

Construction work mostly involves dusty and dirty activities and including manipulation of dangerous substances and chemicals. Hence, washing facilities offered as a basic hygiene measure to prevent chemical from polluting foods and absorbing skin or being carried home. Apart from that, it is purposely use to remove dirt and grime, which also can be ingested and cause sickness and diseases [23]. Washing facilities comprise basins or sinks that allow people to wash their hands, face and forearms [6] [7]. Likewise, it consists of supplying hot and cold, or warm water which should be running water with soup or other washing agents for cleaning activities that are sufficient for the workers. Washing or shower facilities is provided for specific dirty work or work subjecting employees to hazardous substance such as concrete pouring [6]. However, for every $15 \mathrm{em}$ ployees, soap with appropriate drying facilities is provided. Where employees are subjecting to skin contamination by chemical substances or by oil or grease, adequate number of showers should be provided and daily disinfected. Facilities should be sheltered to offer protections to weather conditions, and well ventilated and lit [7] [23]. In the views of [26], the draft facilities for construction sites advocate that at least one shower for each work station should be offered at the minimum rate of one for each 25 people or a ratio of one bath to 25 people. Yet, 
where both males and females are employed, each shower cubicle should have a shower curtain or door, soap holder, and hot and cold water [2]. Again, men and women can used one sinks for washing hands, arms and face. Where separation is provided unisex shower facilities can also be provided under lockable room which can be used by one person at a time [2] [6] [24]. Yet, there should be easy communication when shower cubicles or wash hand basin are separate from the changing rooms [24].

\subsection{Potable Water at Construction Site}

Water is essential for life whiles drinking water is essential for workers in the construction industry, regardless of the kind of job they do. To avert dehydration, employees should always have easy access to a source of potable water. Therefore, it is imperative to give specific attention to water quality and quantity according to HSE [2]. HSE [6] said a supply of clean drinking water should be immediately available at construction site and should be supplied direct from the mains [7]. Store water is protected, against probable contamination and regular change of stored potable water is necessary to prevent it against becoming stale or contaminated. Where required, a clear mark on the bottle drinking water is essential to prevent it being confused with hazardous liquids or water which is not fit to drink. Provision of cups or other drinking vessels at the outlet is necessary, except the water is supplied in an upward jet, which can be drunk easily, for instance drinking fountain [6] [23].

\subsection{Changing Rooms and Lockers at Construction Site}

In the view of CSPAC [24], a contractor should ensure that suitable changing rooms are offered for persons at work, when it becomes important to wear special personal protective equipment (PPE) and for health or other appropriate reasons they cannot be anticipated to change in another area. The changing rooms should be easily accessible, of adequate capacity and provided with seating. If PPE are likely to be polluted by dangerous substances, atmospheric conditions or other conditions the main contractor should offer facilities to enable PPEs to be kept in a place separate from personal clothing and personal belongings and separate changing rooms are provided for both men and women. If changing rooms are not mandatory the main contractor should see to it that every person at work is provided with a place to lock his or her own clothes and personal belongings. Changing rooms should be offered with accessible drying and clothes hangers. Thus, cupboard with hangers can be used to separate wet and dry clothing. Hence, facilities should be offered to keep PPEs from personal clothing [24]. Furthermore, changing room must be kept clean, dry, well ventilated and secure [7].

For smaller site, the office may be adequately used as storage area but required separate lockers as well, since there is a risk of PPEs contaminating personal clothing, items should be stored separately [19]. The minimum floor area for changing room should be 0.5 metres squared $\left(\mathrm{m}^{2}\right)$ per person changing clothes 
at a time, this floor area should consist of bench seating, and exclusive of floors occupied by furniture, fittings, fixed storage space, or any other permanently fixed items, appropriate bench seating in all change rooms should be at least 400 millimeter's ( $\mathrm{mm}$ ) wide and $460 \mathrm{~mm}$ in length for each person using the room at a time. Likewise, sufficient number of secure hooks should be offered for hanging clothes and be spaced at least $460 \mathrm{~mm}$ apart [26].

\subsection{Rest Facilities at Construction Site}

Rest facilities offer shelter from wind and rain. The rest facilities should have sufficient numbers of tables, seating with backs, a means for heating water for drinks and for warming up food (e.g. a gas or electrical heating ring or microwave oven) and be sufficiently heated. Resting arrangement should be made for pregnant women and nursing mothers and provision is made to ensure no food is contaminated by hazardous substance [7].

\subsection{Canteen Facilities}

Canteen must satisfactorily be equipped and protected from the weather, so that one can comfortably eat food brought from home or brought from vendors. Canteen may be used as rest facilities on provision that food is not on sale at the premises [7]. The provision of canteen services save time construction worker might have used to eat outside [27]. Standards variety of tables, benches, individual drinking cups should be provided and place to offer special drinking fountains. It should be situated away from workstations to minimize contact with dirt, dust or dangerous substances. Good standards of hygiene in canteen are crucial. Facilities must be kept in a clean and sanitary condition as well as conform to hygiene and safety requirement.

\section{Research Methodology}

A significant aspect of any study is design. [28] opines that it is the chronological arrangement that links the experiential data to the early questions of the study and, eventually, to its conclusions. The research design is the framework directing the study under investigation, guiding [29]. Research design typology includes an experimental, case study, longitudinal/cross-sectional survey, and/or comparative study [30]. The research designs adopted were cross-sectional survey. Key [31] reported that survey design explains the status quo, the correlation research which investigates the association amid variables, the developmental studies which tend to determine changes over time. This study adopted a quantitative research approach, which is the mathematical representation and manipulation of observations for the intention of explaining and describing the status quo reflecting the observations [32].

\subsection{Study Population and Sample Size}

The target population were all registered building construction firms in Asuogya- 
man District and New Juaben Municipality. However, a sample was taken due to the relatively short period for the completion of the study, as well as resource constraints and the fact that a representative sample could be generalised for the entire population [33]. Meanwhile 10 construction firms from each of the two districts were sample, making 20 construction firm. A sample size of 100 was used by the study. Fifty (50) questionnaires each were sent to construction firms in both Asuogyaman District and New Juaben Municipality. The sampling technique employed for the study was a convenient sample. This was because the researchers collected the data at their locality, thus Asuogyaman District and New Juaben Municipality in Eastern Region due to the covid-19 pandemic.

\subsection{Instruments for Data Collection}

Questionnaires were used to solicit primary data from building construction workers in Asuogyaman District and New Juaben Municipality (Eastern Region) because these groups of people are literate and can therefore read, understand and also answer the items on the questionnaire accordingly. Questionnaires were also employed by [22] and [11] in their studies on welfare facilities issues. The questionnaires were administered by the researchers personally to the various construction firms. Out of the fifty (50) questionnaires sent to Asuogyaman district 42 of the question were retrieved, whiles 38 of the questionnaires were retrieved from new Juaben Municipality. In all 80 of the questionnaires were retrieved representing $80 \%$ of the response rate. [34] stated that with quantitative study $10 \%-30 \%$ of the target population suffices.

\subsection{Pre-Test}

The instruments for data collection were tested from two construction firms in the Eastern Region and two academicians. This functioning as initial means of testing the research questions capacity to produce the required answers for the study. The pre-test intended to allow the researcher to make needed changes to variables which may be unsuitable, determine the level of ambiguity of the questions. Ambiguous items were altered and inappropriate items made appropriate. The questionnaire was administered on the same group of subjects twice in the pilot study with a two-week grace period between the first and the second test and the coefficient of reliability from the two tests correlated. The reliability test produced the Cronbach alpha of 0.89 .

\subsection{Methods of Data Analysis}

The study employs 5-point likert scale to measure how construction workers are satisfied with provision of welfare facilities, where 1 = highly not satisfied, $2=$ not satisfied, 3 = neutral, 4 = satisfied, and 5 = highly satisfied. Whereas 5 -point likert scale employs to measure performance of construction worker on provision of welfare facilities are $1=$ very bad, $2=$ bad, $3=$ neutral, $4=$ good, and $5=$ excellent. The data were analyzed with statistical product for service solutions 
(SPSS). The study employed descriptive statistics such as frequency, percentage, and mean, whiles inferential statistics employed were chi square statistics.

\section{Results and Discussion}

\subsection{Demographic Characteristics of Respondents}

This part presents the demographic background of the respondents. It captures respondents' gender, the experience level of personnel, educational level, and status in the organization. Their responses are presented in Table 1 below.

\subsection{The Important of Welfare Facilities and Its Availability}

The study required the workers to determine how necessary it is to provide welfare facilities on construction site, the finding from the workers indicated in Figure 1 that about $99 \%$ of the respondence agreed that provision of welfare facilities on construction site is important.

Table 1. Demographic characteristics of respondents $(\mathrm{N}=80)$.

\begin{tabular}{|c|c|c|}
\hline Variables & Frequency & Percentage (\%) \\
\hline \multicolumn{3}{|l|}{ Gender } \\
\hline male & 76 & 95.0 \\
\hline female & 4 & 5.0 \\
\hline \multicolumn{3}{|l|}{ educational level } \\
\hline Intermediate/SHS/SSS & 25 & 31.25 \\
\hline Technician & 16 & 20.00 \\
\hline Advance craft & 22 & 27.50 \\
\hline Higher National Diploma & 5 & 6.25 \\
\hline First-degree & 12 & 15.0 \\
\hline \multicolumn{3}{|l|}{ Level of experience } \\
\hline $1-10$ years & 59 & 73.75 \\
\hline $11-20$ years & 21 & 26.25 \\
\hline \multicolumn{3}{|l|}{ status } \\
\hline Engineer & 19 & 23.75 \\
\hline Site supervisor & 16 & 20.0 \\
\hline Project Manager & 13 & 16.25 \\
\hline Quantity Surveyor & 9 & 11.25 \\
\hline Architect & 7 & 8.75 \\
\hline Procurement officer & 7 & 8.75 \\
\hline Timekeeper & 6 & 7.5 \\
\hline Security officer & 3 & 3.75 \\
\hline
\end{tabular}

Source: Researcher's Fieldwork (2020). 


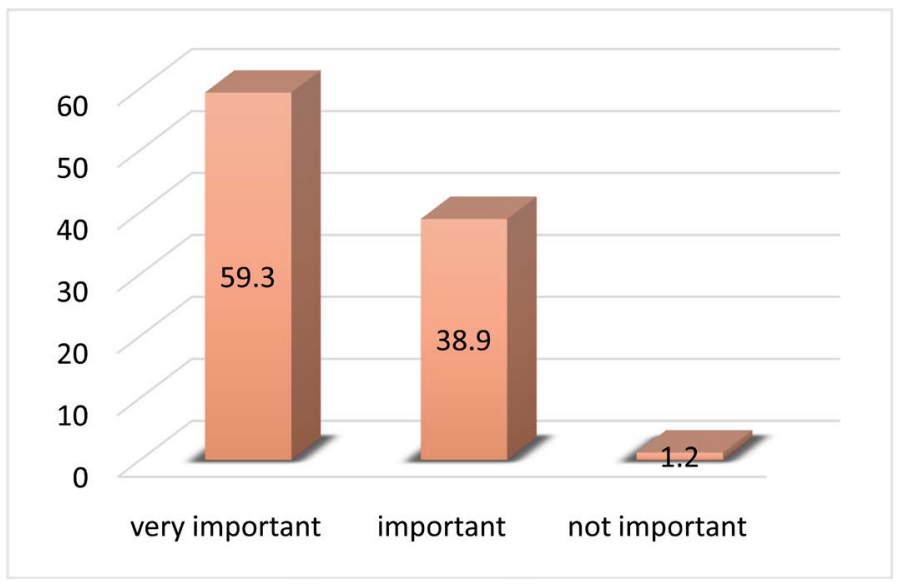

Figure 1. Importance of providing welfare facilities.

\subsection{Extent of Welfare Facilities Availability}

To address the extent of welfare facilities available at the various building construction site, the study investigated the specific welfare facilities available at the building construction firms. The results of the study are shown in Table 2(a), Table 2(b).

From Table 2(a), the finding on the sanitary and toilet facilities reveals that there is $90 \%$ unavailable water closet, $95 \%$ unavailable potable chemical toilet and $97.5 \%$ unavailable urinals at the various construction sites under investigation. The availability of sanitary and toilet facilities on the construction sites are not consistence with that of British Standard (BS) 6465 code of practice for the design of sanitary facilities and scales of provision of sanitary and related appliances because its advocates that, there should be sufficient number of toilet provisions on site for the employees. Inconsistency of the findings is similar to the view of CSPAC [24] and WHSW, [7] that a contractor should ensure that: a minimum of one appropriate sanitary convenience is provided at construction, thus $1 \mathrm{WC}$ or 1 portable chemical toilet, and 1 urinal. However, the study reveals woeful unavailability of washing facilities, thus over $90 \%$ of all the kinds of washing facilities such as wash hand basin, kitchen sink, shower, washing detergent, towels or napkins are unavailable at various site, this finding implied that the employees do not benefit from basic hygienic measures that could assist in removing dirt and grime after day's work and avoiding stead that can cause sickness and diseases [23]. Even after working with concrete, washing or shower facilities are unavailable to assist employees to wash dirty and hazardous substance [6]. Still workers are denied of soup and clean towels and alternate methods of cleaning and drying [7]. Nevertheless, the findings on drinking water availability indicates all forms of drinking water such as direct water supply, provision of sachet water and bottle are available for used, this finding is in line with [2] [6] [7] stipulates that sufficient portable water with appropriate means of drinking should be provided for construction employees. Yet, from Table 2(b) the finding on changing rooms and lockers facilities are disaggregated, in 
Table 2. (a) Extent of welfare facilities; (b) Continuation of extent of welfare facilities.

(a)

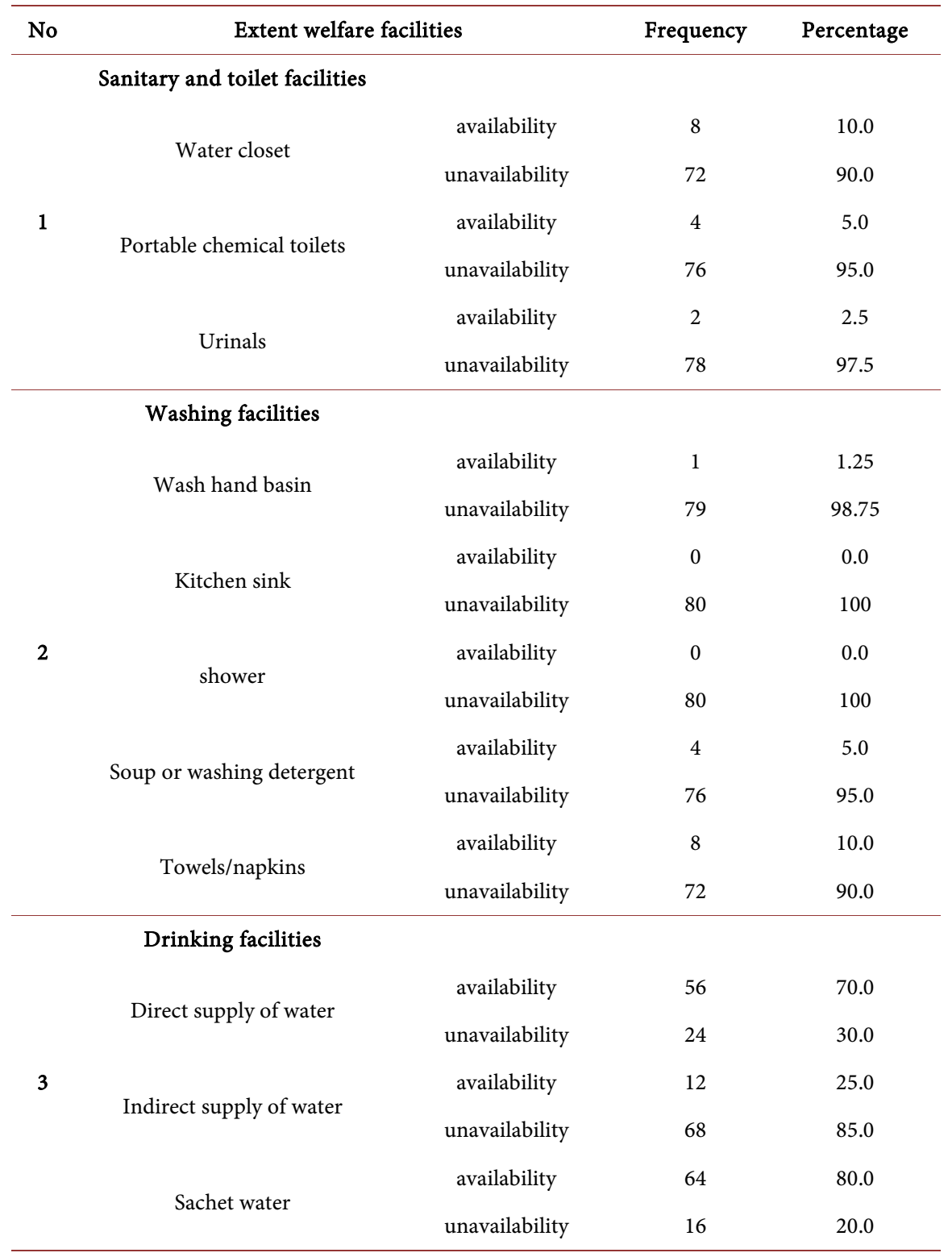

(b)

\begin{tabular}{|c|c|c|c|c|}
\hline No & \multicolumn{2}{|c|}{ Extent welfare facilities } & \multirow{2}{*}{$\begin{array}{c}\text { Frequency } \\
8\end{array}$} & \multirow{2}{*}{$\begin{array}{c}\text { Percentage } \\
10.0\end{array}$} \\
\hline \multirow{8}{*}{4} & & availability & & \\
\hline & Dotule waler & unavailability & 72 & 90.0 \\
\hline & \multicolumn{4}{|c|}{ Changing Rooms and Lockers Facilities } \\
\hline & \multirow{2}{*}{ Seating } & availability & 12 & 85.0 \\
\hline & & unavailability & 68 & 25.0 \\
\hline & \multirow{2}{*}{ Cupboard } & availability & 0 & 0.0 \\
\hline & & unavailability & 80 & 100 \\
\hline & Cloth hungers & availability & 8 & 10.0 \\
\hline
\end{tabular}




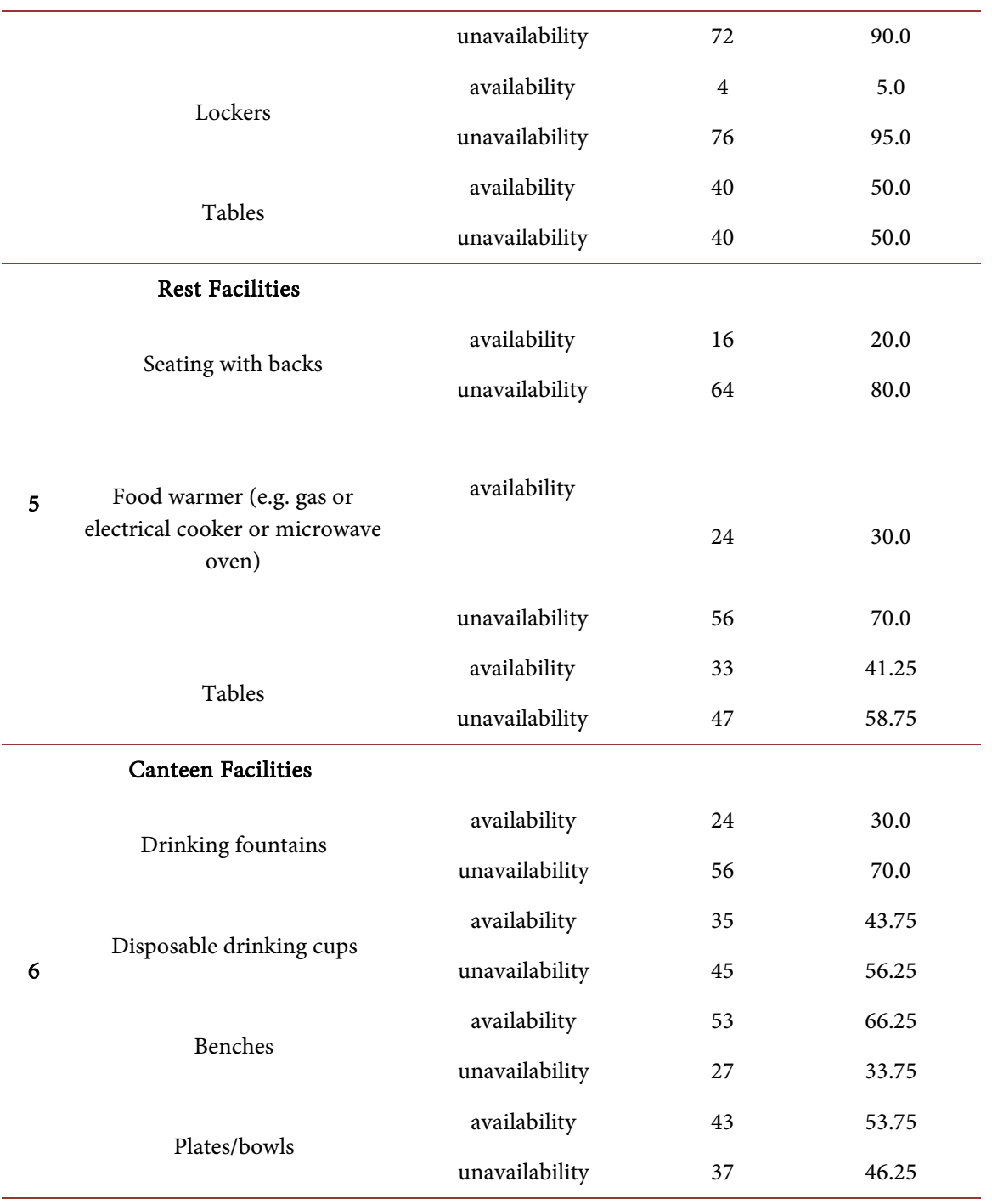

that some form of CRL are available and these include seats and tables and this revelation is consistent with WHSW, [7] and CSPAC [25] position that changing facilities arrangement should be made for workers to change their personal clothing and wear PPEs, whiles over $85 \%$ of some kinds of CRL facilities, such as cupboards, clothing hangers, and lockers are unavailable and these are inconsistent with CSPAC [24]. According to [24] the provision of CRL facilities will keep PPEs from personal clothing. Moreover, the finding on rest facilities reveals that over $70 \%$ of all forms of RF such as seat with back, and food warmers are unavailable and these findings are inconsistent with [2] and [5] the RF should have sufficient numbers seating with backs, a means for heating water for drinks and for warming up food. Whiles WSHW [7] opines that RF is provided at construction site for workers to sit for their relaxation during break time, where they will not require to wear PPEs. Furthermore, the revelation of availability of canteen facilities indicated that over 53\% of some form of CF including benches and plates were available and these are in line with WHSW [7] that provision of CF 
ensures no food is contaminated by hazardous substance. Also, [27] posited that provision of canteen services save time construction worker might have used to eat outside.

\subsection{Satisfaction Level of Employee's Welfare Facilities}

The workers satisfaction level to the welfare facilities at their various construction sites was investigated. The results of the study are presented in Table 3. It was reveals that all the six categories of welfare facilities responded by the workers had the mean value below theoretical mean of 3.0 from 5-point Likert scale, indicating that workers were not satisfied with welfare facilities provided at their various construction site within the Eastern Region of Ghana. The major rank variable was changing rooms and lockers facilities with mean value of 2.6875, follow by Canteen facilities with mean value of 2.5375 . The finding of the study is consistent with [9] who posited that construction employees dissatisfying with insufficient welfare facilities results in low output as well as loss of profit. In another view [35] discovered that workers like satisfaction that is associated with their works and including the joy that comes with facilities provided by construction organisations. Hence the employees give their greater support for organisational growth. The employees are provided with health and safety gadgets and other necessary welfare facilities to aid workers to come out with better performance in their work environment.

\subsection{Provision of Welfare Facilities and Employee's Performance}

The study also investigated whether the provision of welfare facilities at various construction sites could enhance workers performance. As indicated in Table 4, the result reveals that all the six categories of welfare facilities responded to by the workers had the mean value above theoretical mean of 3.0 from 5-point Likert scale, indicating that workers agreed that provision of welfare facilities at construction site enhance their performance. To determine the significance of workers responses, the study was tested at $99 \%$ confident level and the chi square statistics reveals that all the variables for various categories of welfare facilities were rated as significant with 0.000 thus $99 \%$ confident of welfare facilities improving construction workers performance. Hence the hypothesis one is

Table 3. Satisfaction level of employee's welfare facilities.

\begin{tabular}{ccccc}
\hline No & Variable & std Deviation & Mean Score & Ranking \\
\hline 1 & Changing rooms and lockers facilities & 0.54177 & 2.6875 & 1 \\
2 & Canteen facilities & 0.79466 & 2.5375 & 2 \\
3 & Drinking water facilities & 0.69344 & 2.5125 & 3 \\
4 & Sanitary and toilet facilities & 0.93321 & 2.2000 & 4 \\
5 & Washing facilities & 0.79715 & 2.1500 & 5 \\
6 & Rest facilities & 0.57589 & 2.1500 & 6 \\
\hline
\end{tabular}


Table 4. Welfare facilities and employing performance.

\begin{tabular}{|c|c|c|c|c|c|c|c|}
\hline No & Variables & $\begin{array}{c}\text { std } \\
\text { deviation }\end{array}$ & $\begin{array}{l}\text { Mean } \\
\text { score }\end{array}$ & Ranking & $\begin{array}{l}\text { Chi- } \\
\text { Square }\end{array}$ & $\mathrm{df}$ & $\begin{array}{l}\text { Sig. } \\
99 \%\end{array}$ \\
\hline \multicolumn{8}{|c|}{ Employee motivation } \\
\hline 1 & Canteen facilities & 0.54888 & 4.5500 & 1 & $37.900^{\mathrm{a}}$ & 2 & 0.000 \\
\hline 2 & Rest facilities & 0.57355 & 4.5125 & 2 & $33.775^{\mathrm{a}}$ & 2 & 0.000 \\
\hline 3 & Washing facilities & 0.58677 & 4.4000 & 3 & $29.200^{\mathrm{a}}$ & 2 & 0.000 \\
\hline 4 & Drinking water facilities & 0.64128 & 4.3625 & 4 & $21.775^{\mathrm{a}}$ & 2 & 0.000 \\
\hline 5 & $\begin{array}{l}\text { Changing rooms and lockers } \\
\text { facilities }\end{array}$ & 0.65555 & 4.2750 & 5 & $19.075^{\mathrm{a}}$ & 2 & 0.000 \\
\hline 6 & Sanitary and toilet facilities & 0.63595 & 4.2250 & 6 & $66.100^{\mathrm{b}}$ & 3 & 0.000 \\
\hline
\end{tabular}

${ }^{\mathrm{a}} 0$ cells $(.0 \%)$ have expected frequencies less than 5 . The minimum expected cell frequency is 26.7 . ${ }^{\mathrm{b}} 0$ cells $(0.0 \%)$ have expected frequencies less than 5 . The minimum expected cell frequency is 20.0 .

sustained that there is relationship between welfare facilities and construction workers performance.

\section{Conclusions}

Provision of welfare facilities at construction sites is so essential to employee's well-being and health; but all types of welfare facilities provided at the construction site within Asuogyaman District and New Juaben Municipality in the Eastern Region of Ghana were not adequate. Even at some of the construction site, most welfare facilities are not available. Furthermore, workers are not satisfied with the various states of welfare facilities provisions on site. It has been seen that, provision of the welfare facilities enhances construction workers performance and also impact on their health, physical and mental efficiency, alertness, morale and overall efficiency of the worker and contributes to the higher productivity. Provision of a suitable welfare facility should be given a needed attention at a given construction site.

\section{Recommendation}

- The researchers suggest that city authorities should set a task force to enforce the execution of welfare facilities at construction site as the study outcome shows woeful insufficiency of welfare facilities at Eastern Region construction firms.

- There should be a clause in every contract document on implementation of suitable welfare facilities on every building construction site.

- As practice by developed countries, health and safety frame work for Ghanaian construction industry should be developed to assist in monitoring health and safety practices in building construction industry.

\section{Conflicts of Interest}

The authors declare no conflicts of interest regarding the publication of this paper. 


\section{References}

[1] Pooja, V. and Kahkashan, K. (2020) The Study of Employees Satisfaction Level in Banking Sector (with Special Reference to Gorakhpur Region). Sustainable Humanosphere, 16, 483.

[2] Health and Safety Executive (2010) Provision of Welfare Facilities during Construction Work, Construction Information Sheet 59.

http://www.hse.gov.uk/pubns/cis62.pdf

[3] Health and Safety Executive (2007) Construction (Design and Management) Regulations. The Stationary Office Limited, London.

[4] Ghana Labour Act (2003) Arrangement of Sections. Labour Act 651, National Labour Commission, Accra.

[5] Health and Safety Executive (2015) Construction (Design and Management) Regulations. The Stationary Office Limited, London.

[6] Health and Safety Executive (2007) Welfare at Work: Guidance for Employers on Welfare Provisions. http://www.hse.gov.uk/pubns/indg293.pdf

[7] Health and Safety Executive (2013) Workplace Health, Safety and Welfare Regulations. 2nd Edition, Health and Safety Executive, Bootle, 57

[8] Hiba, J.C. (1998) Improving Working Conditions and Productivity in the Garment Industry. International Labour Office Publications, Geneva.

[9] Government of Ghana (2003) Factories, Offices and Shops Act, 1970. Government of Ghana, Accra.

[10] Premarathne, M.A.D.T. and Perera, G.D.N. (2017) The Effect of Welfare Facilities on Employee Retention in a Selected Company in Sri Lanka. Proceedings of 2 nd International HRM Conference, Nugegoda, 17th October 2015, Vol. 2, 116-124.

[11] Gyansah, N.T. (2016) Investigation into Worker Satisfaction with Construction Site Welfare Provisions. Kwame Nkrumah University of Science and Technology, Kumasi.

[12] Dok-Yen, D.M., Nana Tabi, K. and Adinyira, E. (2018) Assessing the Adequacy of Welfare Facilities on Construction Sites in Ghana. International Journal of Construction Engineering and Management, 7, 162-167.

[13] Opatha, H.H.D.N.P. (2002) Performance Evaluation of Human Resources. Institute of Management and Science, Colombo.

[14] Kossivi, B., Xu, M. and Kalgora, B. (2016) Study on Determining Factors of Employee Retention. Open Journal of Social Sciences, 4, 261-268.

http://dx.doi.org/10.4236/jss.2016.45029

[15] Mangel, R. and Useem, M. (2000) The Strategic Role of Gainsharing. Journal of Labor Research, 21, 327-343. https://doi.org/10.1007/s12122-000-1051-y

[16] Meyer, G.J., Finn, S.E., Eyde, L.D., Kay, G.G., Moreland, K.L., Dies, R.R., Eisman, E.J., Kubiszyn, T.W. and Reed, G.M. (2001) Psychological Testing and Psychological Assessment: A Review of Evidence and Issues. American Psychologist, 56, 128-165. https://doi.apa.org/doi/10.1037/0003-066X.56.2.128

[17] Carraher, S.M. (2011) Turnover Prediction Using Attitudes towards Benefits, Pay, and Pay Satisfaction among Employees and Entrepreneurs in Estonia, Latvia, \& Lithuania. Baltic Journal of Management, 6, 25-52. https://doi.org/10.1108/17465261111100905

[18] Laryea, S. (2010) Health and Safety on Construction Sites in Ghana. The Construction, Building and Real Estate Research Conference of the Royal Institution of 
Chartered Surveyors, Paris, 2-3 September 2010, Article ID: 16289. http://centaur.reading.ac.uk/16289/

[19] Health and Safety Executive (1998) Provision of Welfare Facilities at Fixed Construction Sites, Construction Information Sheet No 18(rev1).

[20] Ridley, J., John, C. and Laschinger, H.K. (1999) Work Place Safety. 4th Edition, Butterworth-Heinemann Ltd., Oxford.

[21] Suresh, G. and Vijayarani, K. (2015) Intra-Mural and Extra-Mural Welfare Facilities. International Journal of World Research, 1, 94-104.

[22] Arpit, P., Archana, G. and Heli, S. (2017) A Study on Labour Welfare Measures and Social Security on Selected Engineering Unit of Ahmadabad. Journal of Management \& Research, 6, 19-26. https://doi.org/10.17697/ibmrd/2017/v6i1/111654

[23] International Labour Office (1992) Safety and Health in Construction: An ILO Code of Practice. International Labour Office Publications, Geneva.

[24] Construction Safety Partnership Advisory Committee (2016) Requirements for construction Site Welfare Facilities.

[25] British Standard Code 6465-1 (2006) Sanitary Installations. Code of Practice for the Design of Sanitary Facilities and Scales of Provision of Sanitary and Associated Appliances.

[26] Anon, E. (2010) Facilities for Construction Sites, Draft Code of Practice. https://submissions.swa.gov.au/SWAforms/Facilities

[27] Tan, J.Y. (2010) Construction Site Layout Planning for Residential Project. Universiti Teknologi Malaysia, Johor.

[28] Sarantakos, S. (2005) Social Research. Palgrave Macmillan, Hampshire.

[29] Creswell, J.W. and Creswell, J.D. (2018) Research Design: Qualitative, Quantitative, and Mixed Methods Approaches. Sage, Los Angeles.

[30] Awahyuni, D. (2012) The Research Design Maze: Understanding Paradigms, Cases, Methods and Methodologies. Journal of Applied Management Accounting Research, 10, 69-80.

[31] Key, J.P. (1997) Research Design in Occupational Education. Oklahoma State University.

[32] Babbie, E. (2005) The Basics of Social Research. Thomson Wadsworth, Belmont.

[33] Creswell, J.W. (2003) Research Design: Qualitative, Quantitative and Mixed-Methods Approaches. 2nd Edition, Sage, Thousand Oaks.

[34] Asamoah-Gyimah, K. and Duodu, F. (2007) Introduction to Research Methods in Education. Institute for Educational Development and Extension, Winneba

[35] Logasakthi K. and Rajagopal K. (2013) A Study on Employee Health, Safety and Welfare Measures of Chemical Industry in the View of Sleam Region, Tamil Nadu (India). International Journal of Research in Business Management, 1, 1-10. 